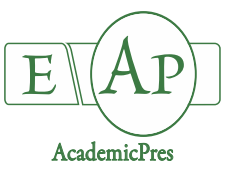

Silalert P and Pattanagul W (2021)

Notulae Botanicae Horti Agrobotanici Cluj-Napoca

Volume 49, Issue 3, Article number 12417

DOI: $10.15835 /$ nbha 49312417

Research Article

\title{
Foliar application of melatonin alleviates the effects of drought stress in rice (Oryza sativa L.) seedlings
}

\author{
Parichart SILALERT, Wattana PATTANAGUL*
}

Khon Kaen University, Faculty of Science, Department of Biology, 123 Moo 16 Mittraphap Road, Nai-Muang sub district,

Muang District, Khon Kaen 40002, Thailand; parichart_s@kkumail.com; wattana@biology.in.th (*corresponding author)

\begin{abstract}
Melatonin ( $N$-acetyl-5-methoxytryptamine) plays an essential role in abiotic stress in plants, but its mechanism in drought tolerance is unclear. To better understand the protective roles of melatonin against drought stress, we investigated the effect of foliar application with exogenous melatonin on plant growth, physiological responses, and antioxidant enzyme activities in rice seedlings under drought stress. Rice seedlings were grown for 21 days, and foliar sprayed with $0,50,100,200$, and $300 \mu \mathrm{M}$ melatonin. The control plant was watered daily, while the others were subjected to drought stress by withholding water for seven days. The results showed that drought stress significantly reduced plant growth, relative water content, and chlorophyll content. Electrolyte leakage, malondialdehyde (MDA) content and hydrogen peroxide $\left(\mathrm{H}_{2} \mathrm{O}_{2}\right)$ were also negatively affected by drought stress. Application of melatonin alleviated the effects of drought stress by increasing plant growth, improving relative water content and chlorophyll content, and decreasing electrolyte leakage, MDA, and $\mathrm{H}_{2} \mathrm{O}_{2}$. Foliar application with melatonin also increased antioxidant enzyme activities, including superoxide dismutase (SOD), catalase (CAT), ascorbate peroxidase (APX), and guaiacol peroxidase (GPX). In addition, melatonin also enhanced proline and total soluble sugar accumulation during drought stress. It is, therefore, suggested that foliar application with $100 \mu \mathrm{M}$ melatonin was the most effective for reducing the adverse effects of drought stress in rice plants.
\end{abstract}

Keywords: antioxidant enzymes; drought stress; foliar application; melatonin

\section{Introduction}

Rice (Oryza sativa L.) is a staple crop widely cultivated in Thailand and exported worldwide (Siriphollakul et al., 2017). One of the most famous rice in Thailand is Thai jasmine rice or 'Khao Dawk Mali 105 ' (KDML 105) rice because of its aroma and tender cooking properties. Unfortunately, drought stress is still a significant limitation to rice production in Thailand, especially in the Northeastern region of Thailand, where this cultivar is popularly cultivated (Polthanee et al., 2014). Drought stress is one of the major abiotic stresses restricting crop growth and yield because it adversely affects many biochemical and physiological processes in plants. Drought stress induces stomatal closure, resulting in a lower transpiration rate and reduced photosynthesis (Farooq et al., 2009). Also, drought stress induces the generation of reactive oxygen species (ROS), leading to lipid peroxidation and ultimately causes membrane dysfunction (Li et al., 2011; Liang et al., 2019). In order to maintain the ROS balance and alleviate cellular oxidative injuries, plants have evolved 
antioxidant defence mechanisms, either non-enzymatic antioxidant such as glutathione, ascorbic acid carotenoids or enzymatic antioxidants, including superoxide dismutase (SOD), catalase (CAT), ascorbate peroxidase (APX), and guaiacol peroxidase (GPX) (Apel and Hirt, 2004; Mittler et al., 2004). These antioxidant mechanisms are essential in plants, as they help maintaining the stability and integrity of the cell membrane. Moreover, the accumulation of compatible solutes, such as soluble sugar, glycine betaine and proline also play a vital role in drought tolerant mechanisms. Proline accumulation is believed to play multiple roles beyond osmotic adjustment in the adaptation to drought stress by acting as an antioxidative defence molecule and a signalling molecule (Verbruggen and Hermans, 2008; Hayat et al., 2012).

Recently, plant growth regulators have been widely used to regulate plant growth and improve plant stress tolerance. Melatonin ( $N$-acetyl-5-methoxytryptamine) is an indole hormone widely present in plants and animals. It was identified and quantified for the first time in plants in 1995 (Dubbels et al., 1995). It performs various functions in plant growth, development, and stress responses (Shi et al., 2016). Melatonin plays multiple roles in plants, including increasing seed germination, promoting lateral root development, delaying leaf senescence, protecting plants from stress, and increasing crop yield (Zhang et al., 2013; Ahmad et al., 2020). Moreover, melatonin has been demonstrated as an effective plant biostimulant against biotic and abiotic stresses (Arnao and Hernández-Ruiz, 2021). Melatonin triggers the accumulation of compatible solutes such as total soluble sugars and proline content (Sharma et al., 2020). Many studies reported that exogenous melatonin could enhance plant tolerance to drought stress (Wei et al., 2015; Zhang et al., 2015). For example, melatonin alleviates oxidative damage during drought stress by directly scavenging ROS resulted in decreases in electrolyte leakage and MDA content and by enhancing antioxidant enzyme activities (Ye et al., 2016; Cherono et al., 2021). Melatonin also has crosstalk with other plant growth regulators such as gibberellin, jasmonic acid, and abscisic acid to regulate various physiological processes in plants under drought stress. In addition, melatonin regulates the transcription of various essential genes involved in antioxidative defense mechanisms (Sharma et al., 2020).

The role of melatonin under drought stress has been reported in many plant species. Its mechanism and effective concentration in each species, however, remain unclear. Therefore, it is intriguing to investigate the effects of melatonin on 'Khao Dawk Mali 105' rice which is the major economic crop of Thailand. This study aimed to investigate the efficacy and appropriate concentration of exogenous melatonin in alleviating the negative effects of drought in rice. Physiological responses and antioxidant enzyme activities were also determined to better understand the mechanism of melatonin in drought tolerant mechanism.

\section{Materials and Methods}

\section{Plant material and growth conditions}

Rice seeds (Oryza sativa L. cv. 'Khao Dawk Mali 105') were surface sterilized in 3\% sodium hypochlorite for $10 \mathrm{~min}$ and rinsed with distilled water. The seeds were then soaked in distilled water for $48 \mathrm{~h}$ and germinated on moistened filter paper for three days in the dark. After that, the germinated seedlings were transferred into black plastic pots (diameter: $20 \mathrm{~cm}$, height: $15 \mathrm{~cm}$ ) filled with $4 \mathrm{~kg}$ of soil (loamy sand; $\mathrm{pH}$

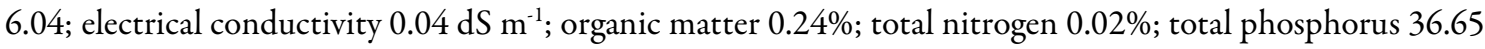
$\mathrm{mg} \mathrm{kg}^{-1}$, and total potassium $234.50 \mathrm{mg} \mathrm{kg}^{-1}$ ), with ten seedlings per pot. The seedlings were watered daily with distilled water $(500 \mathrm{ml} /$ pot/day) and allowed to grow for 21 days in the greenhouse under natural light with an average temperature of $28.90{ }^{\circ} \mathrm{C}$ and average humidity of $68.36 \%$ at Khon Kaen University, Khon Kaen, Thailand. The seedlings were then divided into six groups, including the control group (well-watered), MT0 (foliar spray with distilled water), foliar spray with 50 (MT50), 100 (MT100), 200 (MT200), and 300 (MT300) $\mu \mathrm{M}$ melatonin. The plants were sprayed to a runoff in the late morning (10.00 a.m.) and repeated for three days. The seedlings were then subjected to drought stress by with holding water for seven days or until rice leaves roll in O-shaped or scale 7 according to 0-9 leaf rolling scale of standard evaluation system for rice 
(International Rice Research Institute, 2002) except the control group which was watered daily with distilled water.

\section{Measurement of plant growth}

After withholding water for seven days, the seedlings were uprooted, washed with tap water, and lightly wiped with a paper towel to remove excess water. The plants were separated into the shoot and root parts. Shoot length, root length, shoot fresh weight, and root fresh weight was recorded. For dry weight analysis, the samples were dried in a hot air oven at $80^{\circ} \mathrm{C}$ for three days.

\section{Chlorophyll content}

Chlorophyll content was determined following the method described by Arnon (1949). About $20 \mathrm{mg}$ of leaf tissues were extracted with $5 \mathrm{ml}$ of $80 \%$ acetone. Chlorophyll extract was measured spectrophotometrically at 645 and $663 \mathrm{~nm}$.

\section{Relative water content}

Fresh leaf was cut into the size of $1.5 \times 1.5 \mathrm{~cm}^{2}$ and immediately weighted to obtain fresh weight (FW). The leaf piece was subsequently floated on deionized water for $4 \mathrm{~h}$ and weighed as turgid weight (TW). After that, the leaf piece was dried at $70^{\circ} \mathrm{C}$ for $48 \mathrm{~h}$ and weighed as dry weight (DW). Relative water content (RWC) was calculated according to the formula (Turner, 1981): RWC $=[($ FW-DW $) /($ TW-DW $)] \times 100$.

\section{Electrolyte leakage}

Approximately $0.1 \mathrm{~g}$ of leaf tissue was immersed in $10 \mathrm{ml}$ of distilled water at room temperature for 24 h. The electrical conductivity of the samples was measured with a conductivity meter (model FE30 FiveEasy', Mettler Toledo, USA) and recorded as $\mathrm{EC}_{1}$. The sample was then boiled at $100^{\circ} \mathrm{C}$ for $30 \mathrm{~min}$. After cooling down, the electrical conductivity of the samples was measured and recorded as $\mathrm{EC}_{2}$. Electrolyte leakage (EL) was calculated using the following formula (Dionisio-Sese and Tobita, 1998): $\mathrm{EL}=\left(\mathrm{EC}_{1} / \mathrm{EC}_{2}\right) \times 100$.

\section{Hydrogen peroxide content}

Approximately $0.1 \mathrm{~g}$ of leaf sample was extracted with $5 \mathrm{ml}$ of $0.1 \%$ trichloroacetic acid (TCA) and then centrifuged at 12,000 rpm for $15 \mathrm{~min}$. Then, $0.5 \mathrm{ml}$ of supernatant was combined with $0.5 \mathrm{ml}$ of $10 \mathrm{mM}$ phosphate buffer ( $\mathrm{pH} 7.0$ ), and $1 \mathrm{ml}$ of $1 \mathrm{M}$ potassium iodide (KI). The absorbance was determined at $390 \mathrm{~nm}$, and $\mathrm{H}_{2} \mathrm{O}_{2}$ content was calculated using a standard curve plotted with the known concentration of $\mathrm{H}_{2} \mathrm{O}_{2}$ (Sergiev et al., 1997).

\section{Malondialdehyde content}

Approximately $0.1 \mathrm{~g}$ of leaf tissue was extracted with $5 \mathrm{ml}$ of $0.1 \%$ trichloroacetic acid (TCA) and centrifuged at $10,000 \mathrm{rpm}$ for $10 \mathrm{~min}$. Then $0.5 \mathrm{ml}$ of supernatant was combined with $1.5 \mathrm{ml}$ of $0.5 \%$ thiobarbituric acid (TBA) in $20 \%$ TCA. The mixture was incubated in a water bath at $95^{\circ} \mathrm{C}$ for $30 \mathrm{~min}$. The reaction was terminated by rapid cooling on ice for $10 \mathrm{~min}$, and the samples were then centrifuged at 10,000 $\mathrm{rpm}$ for $5 \mathrm{~min}$. The absorbance was measured at 532 and $600 \mathrm{~nm}$ using a spectrophotometer. The concentration of TBA reacting substance (TBARS) was calculated using a molar extinction coefficient of 155 $\mathrm{mM}^{-1} \mathrm{~cm}^{-1}$ (Heath and Packer, 1968).

\section{Proline content}

The proline content was assayed as described by Bates et al. (1973) with minor modifications. Approximately $100 \mathrm{mg}$ of leaf tissue was homogenized in $5 \mathrm{ml}$ of $3 \%$ sulfosalicylic acid. The extract was filtered through Whatman filter paper No.1, and $2 \mathrm{ml}$ of supernatant was mixed with $2 \mathrm{ml}$ of glacial acetic acid and 2 $\mathrm{ml}$ of ninhydrin reagent. The reaction mixture was boiled at $100^{\circ} \mathrm{C}$ for $1 \mathrm{~h}$. After cooling by immersion in an 
ice bath to stop the reaction, $4 \mathrm{ml}$ of toluene was added, and the test tube was well vortexed. Then, the absorbance was measured at $520 \mathrm{~nm}$, and the proline content was calculated from a standard curve plotted with the known concentration of proline.

\section{Total soluble sugar content}

Total soluble sugar content was assayed by phenol-sulfuric method described by Dubois et al. (1956). Approximately $50 \mathrm{mg}$ of leaf tissue was extracted with $10 \mathrm{ml}$ of $80 \%$ ethanol. The reaction mixture consisted of $100 \mu \mathrm{l}$ of extracted sugar solution, $500 \mu \mathrm{l}$ of $5 \%$ (W/V) phenol and $1 \mathrm{ml}$ of sulfuric acid $\left(\mathrm{H}_{2} \mathrm{SO}_{4}\right)$ was incubated at room temperature for $10 \mathrm{~min}$ and homogeneously mixed. The reaction was continuously incubated at room temperature for $30 \mathrm{~min}$. Finally, the absorbance was measured at $490 \mathrm{~nm}$, and total soluble sugar content was calculated using the standard curve plotted with known concentration of glucose.

\section{Antioxidant enzyme activities}

About $0.2 \mathrm{~g}$ of fresh leaf sample was ground with $4 \mathrm{ml}$ of grinding buffer containing $50 \mathrm{mM}$ phosphate buffer (pH 7.8), $0.4 \mathrm{mM}$ EDTA, and $1 \mathrm{mM}$ ascorbic acid. The extracts were centrifuged at $12,000 \mathrm{rpm}$ at $4{ }^{\circ} \mathrm{C}$ for $30 \mathrm{~min}$, and the crude extract was used for enzymatic activity assays. Superoxide dismutase (SOD) activity was assayed by measuring its ability to inhibit the photochemical reduction of nitro blue tetrazolium chloride (Gong et al., 2005). The reaction mixture contained $50 \mathrm{mM}$ phosphate buffer ( $\mathrm{pH} 7.8$ ), $0.4 \mathrm{M}$ methionine, 2 $\mathrm{mM}$ NBT, $16 \mathrm{mM}$ EDTA, $1 \mathrm{mM}$ riboflavin, and $50 \mu \mathrm{l}$ of enzyme extract in a final volume of $2 \mathrm{ml}$. The test tubes were exposed to fluorescence light for $30 \mathrm{~min}$, and the absorbance was measured at $560 \mathrm{~nm}$. Catalase (CAT) activity was assayed by measuring the rate of disappearance of $\mathrm{H}_{2} \mathrm{O}_{2}$ using the method described by Hamurcu et al. (2013). The reaction mixture contained $50 \mathrm{mM}$ phosphate buffer ( $\mathrm{pH} 7.0), 0.5 \mathrm{M} \mathrm{H}_{2} \mathrm{O}_{2}$, and $100 \mu \mathrm{l}$ of enzyme extract in a final volume of $2 \mathrm{ml}$. The decrease in $\mathrm{H}_{2} \mathrm{O}_{2}$ was followed by a decline in absorbance at $240 \mathrm{~nm}$. Ascorbate peroxidase (APX) activity was determined according to Sunohara and Matsumoto (2004). The reaction mixture contained $50 \mathrm{mM}$ phosphate buffer ( $\mathrm{pH}$ 7.0), $16 \mathrm{mM}$ EDTA, $20 \mathrm{mM}$ ascorbic acid, $0.5 \mathrm{M} \mathrm{H}_{2} \mathrm{O}_{2}$, and $100 \mu \mathrm{l}$ of enzyme extract. $\mathrm{H}_{2} \mathrm{O}_{2}$ dependent oxidation of ascorbate was followed by a decrease in the absorbance at $290 \mathrm{~nm}$. Guaiacol peroxidase (GPX) activity was determined by the method described by Zhang et al. (2005). The reaction mixture consisted of $50 \mathrm{mM}$ phosphate buffer ( $\mathrm{pH} 7.0$ ), $0.5 \mathrm{M}$ $\mathrm{H}_{2} \mathrm{O}_{2}$, and $3 \%$ guaiacol. The reaction was started by adding $100 \mu$ of enzyme extract to the reaction mixture at $25^{\circ} \mathrm{C}$. The increase in absorbance at $470 \mathrm{~nm}$ due to guaiacol oxidation was recorded for $2 \mathrm{~min}$.

\section{Statistical analysis}

The experiment was designed as a completely randomized design with five replicates. All data were analysed via IBM SPSS statistics 24 , and values were presented as the mean \pm standard error. The data were evaluated by one-way ANOVA using Duncan's multiple range tests $(P<0.05)$.

\section{Results}

Effects of exogenous melatonin on rice seedling growths under drought stress

Drought stress reduced plant growth significantly, as evidenced by decreases in shoot and root length, shoot and root fresh weight, and shoot and root dry weight. Foliar application with 50 and $100 \mu \mathrm{M}$ melatonin showed significantly higher shoot and root length compared to the untreated group (Figure 1A, 1B). Similarly, treating the plant with 50 and $100 \mu \mathrm{M}$ melatonin also resulted in higher shoot fresh and dry weight, as well as higher root fresh and dry weight compared to the untreated group (Figure 1C, 1D, 1E, 1F). High concentrations of melatonin, i.e., 200 and $300 \mu \mathrm{M}$, had no beneficial effects, and plant growth was nearly similar to the untreated plant. 

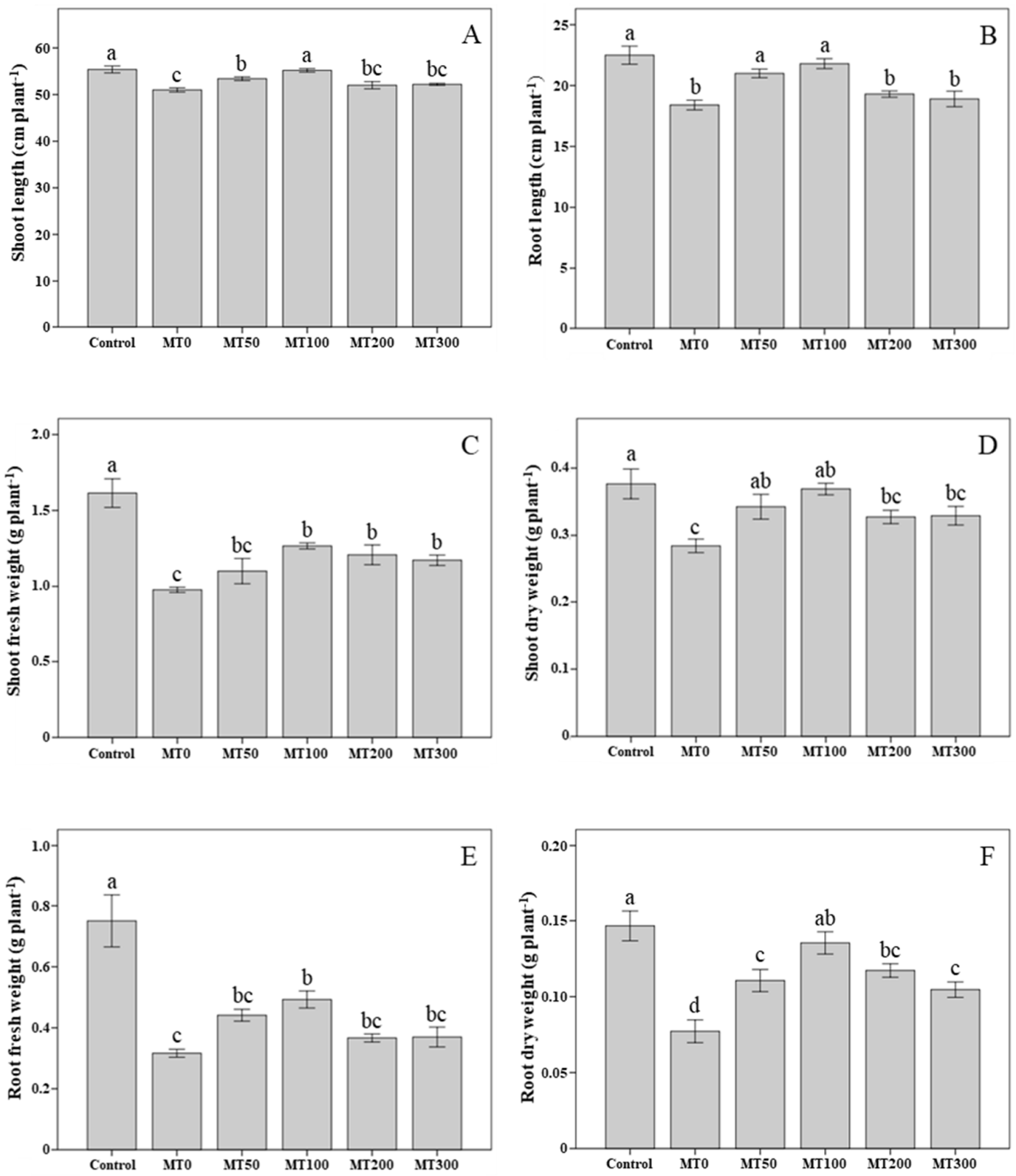

Figure 1. Effects of exogenous melatonin on shoot length (A), root length (B), shoot fresh weight (C), shoot dry weight $(D)$, root fresh weight $(E)$, and root dry weight $(F)$ of rice seedling under drought stress Data represent mean \pm SE of 5 replicate samples. Different letters indicate significant differences according to Duncan's multiple range tests $(P<0.05)$

\section{Effects of exogenous melatonin on chlorophyll content in rice seedling leaves under drought stress}

Drought stress had a detrimental effect on the chlorophyll $a$, chlorophyll $b$, and total chlorophyll levels in rice seedling leaves. Foliar application of melatonin at a concentration of $100 \mu \mathrm{M}$ resulted in a significant increase in chlorophyll content relative to untreated plants, whereas other concentrations including 50,200, and $300 \mu \mathrm{M}$ resulted in slight increases in chlorophyll content. (Figure 2A, 2B, 2C). 

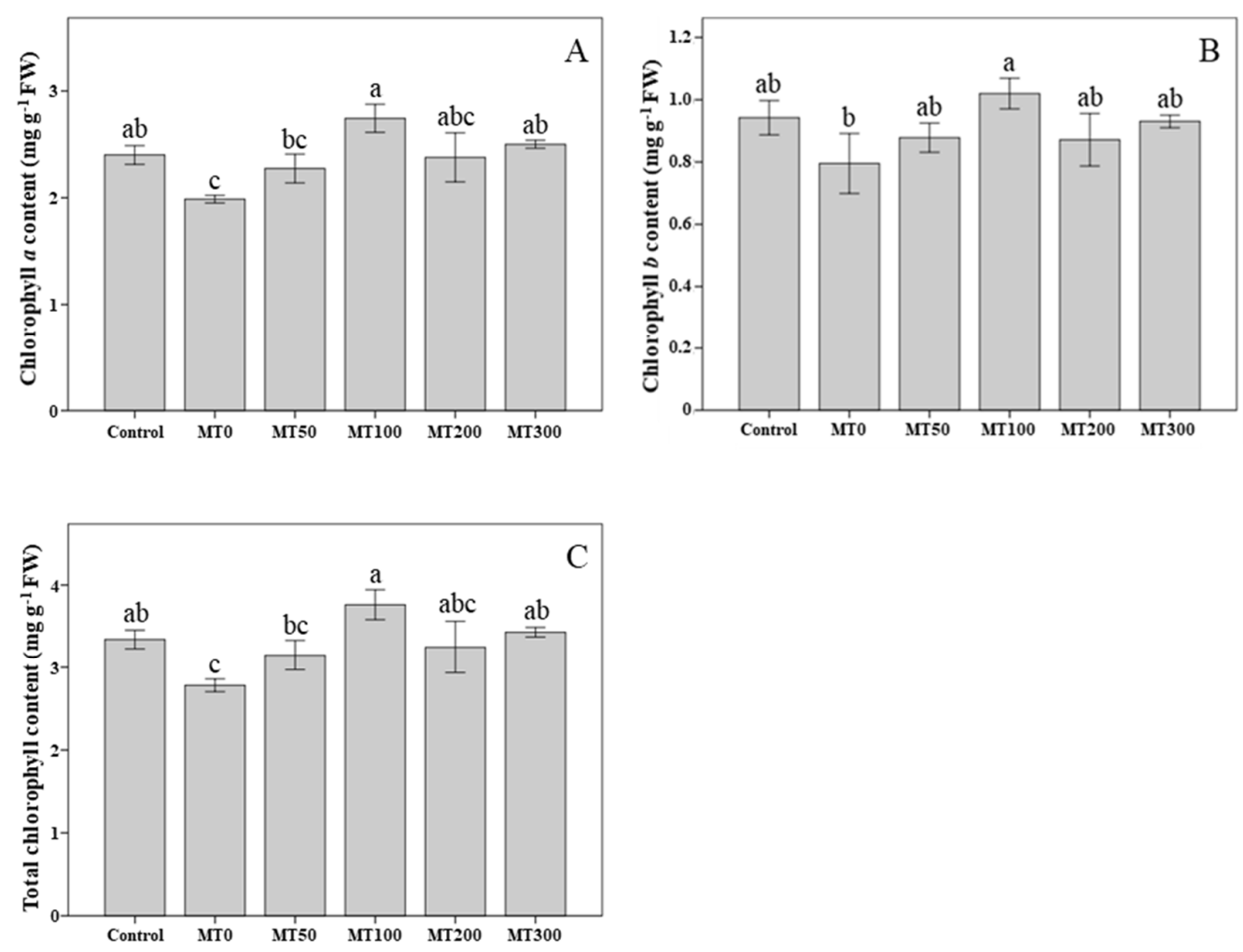

Figure 2. Effects of exogenous melatonin on chlorophyll a content (A), chlorophyll $b$ content (B), and total chlorophyll content $(\mathrm{C})$ in rice seedling leaves under drought stress

Data represent mean \pm SE of 5 replicate samples. Different letters indicate significant differences according to Duncan's multiple range tests $(P<0.05)$

Effects of exogenous melatonin on relative water content, electrolyte leakage, $\mathrm{H}_{2} \mathrm{O}_{2}$ content, and MDA content in rice seedling leaves under drought stress

Drought stress resulted in a significant decrease in the leaf relative water content. Relative water content was reduced from $87.05 \%$ in the control plants to $62.64 \%$ in the untreated plants. Foliar applications with melatonin significantly increased relative water content and showed higher relative water content than the untreated plants. However, the values are not significantly different across melatonin concentrations (Figure 3A). On the other hand, electrolyte leakage increased approximately two-fold when the plant was subjected to drought stress. Exogenous application of melatonin resulted in a significant reduction in electrolyte leakage compared to the untreated plant (Figure 3B). The values, however, were not significantly different between each concentration of melatonin treatment. Under drought stress, $\mathrm{H}_{2} \mathrm{O}_{2}$ content in the leaf increased significantly when compared to the control plant. The seedling treated with exogenous melatonin showed significantly lower $\mathrm{H}_{2} \mathrm{O}_{2}$ than the untreated plant (Figure 3C). However, $\mathrm{H}_{2} \mathrm{O}_{2}$ content was not significantly different across the concentrations of melatonin. Similarly, MDA, a product of membrane lipid peroxidation, showed a significant increase when the plant was subjected to drought stress. Treating the plant with melatonin also alleviates membrane damage, as evidenced by the reduction in MDA content (Figure 3D). 

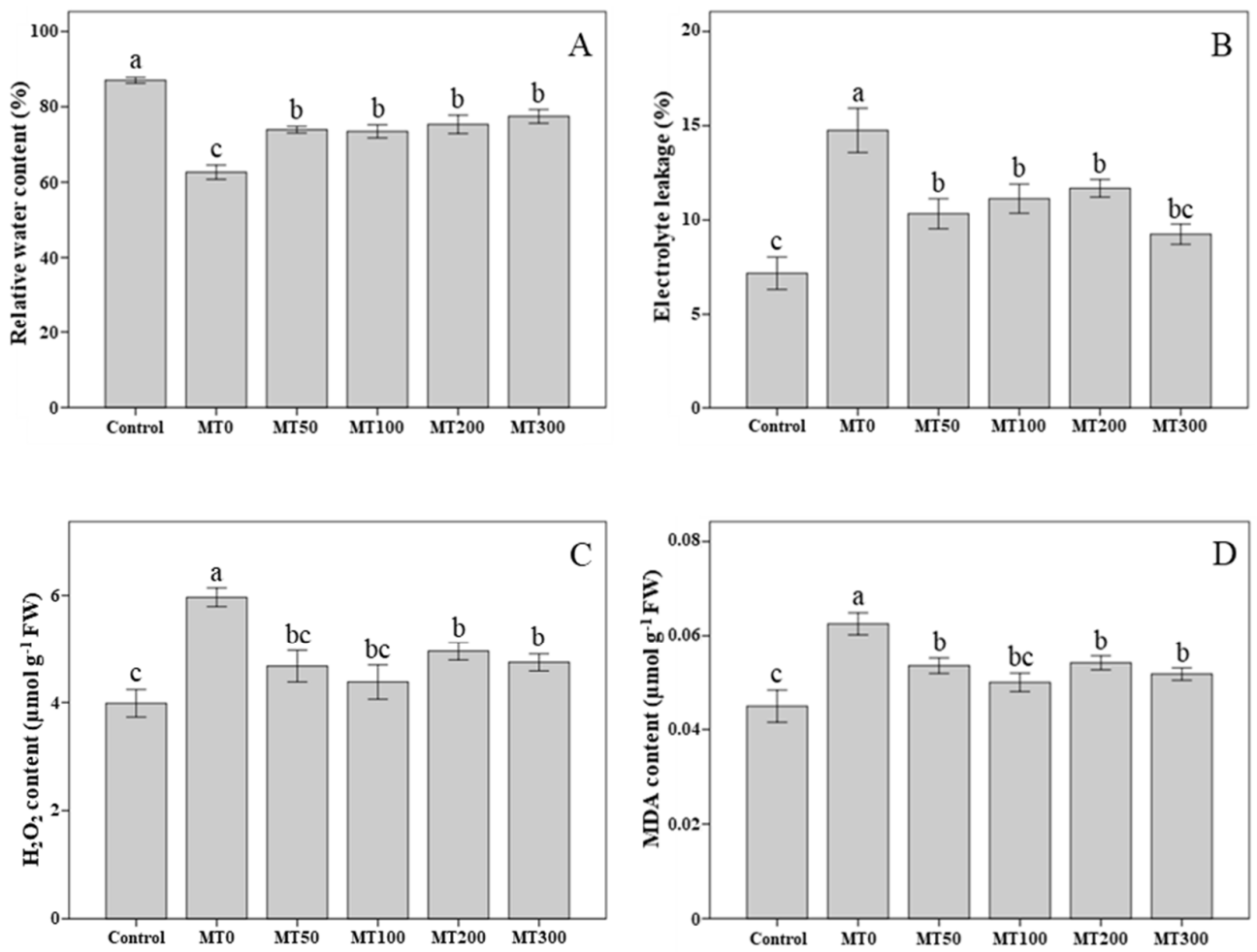

Figure 3. Effects of exogenous melatonin on relative water content (A), electrolyte leakage (B), $\mathrm{H}_{2} \mathrm{O}_{2}$ content (C), and MDA content (D) in rice seedling leaves under drought stress

Data represent mean \pm SE of 5 replicate samples. Different letters indicate significant differences according to Duncan's multiple range tests $(P<0.05)$

Effects of exogenous melatonin on proline content and total soluble sugar content in rice seedling leaves under drought stress

Under drought stress, proline content in the leaf increased approximately 10 -fold compared to the control plant. Treating the plant $100 \mu \mathrm{M}$ melatonin resulted in a significantly higher proline accumulation, while the other concentrations showed no difference in proline content compared to the untreated plant (Figure 4A). In addition, total soluble sugar was also significantly increased by drought stress. Exogenous application of melatonin increased sugar accumulation at all concentrations, with $100 \mu \mathrm{M}$ melatonin resulting in the highest total soluble sugar content (Figure 4B).
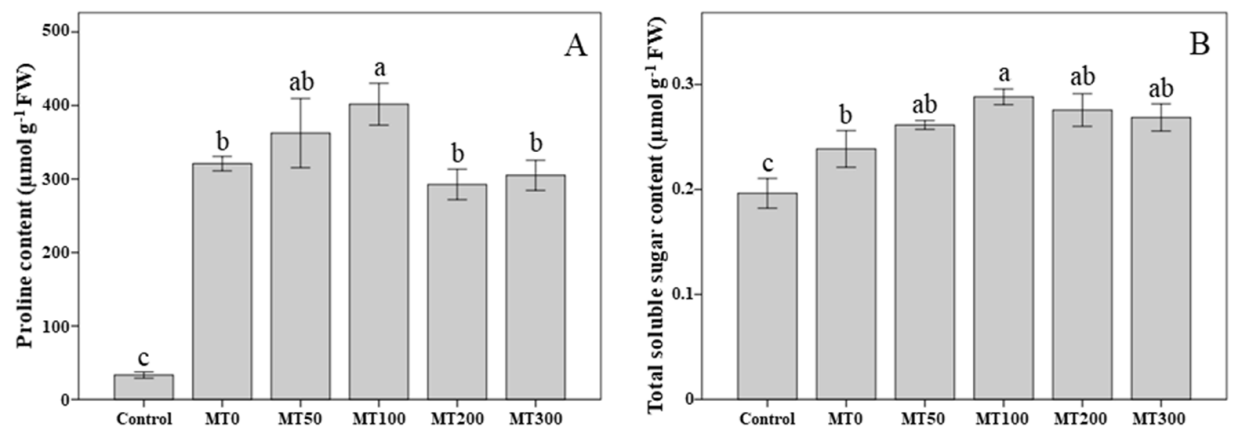

Figure 4. Effects of exogenous melatonin on proline content $(\mathrm{A})$ and total soluble sugar content $(\mathrm{B})$ in rice seedling leaves under drought stress

Data represent mean \pm SE of 5 replicate samples. Different letters indicate significant differences according to Duncan's multiple range tests $(P<0.05)$ 
Effects of exogenous melatonin on antioxidant enzyme activities in rice seedling leaves under drought stress

Antioxidant enzyme activities, including SOD, CAT, APX, and GPX, were determined to understand the effects of drought and exogenous melatonin on the enzymatic antioxidant system. SOD activity increased slightly after the plant was subjected to drought stress. Treating with exogenous melatonin showed no significant difference in SOD activity compared to the untreated plant, except in the $100 \mu \mathrm{M}$ treatment which resulted in a slight increase in SOD activity (Figure 5A). CAT activity in the droughted plant was not significantly different compared to the control plant. Treating with exogenous melatonin showed increases in CAT activity, with $100 \mu \mathrm{M}$ resulting in the highest CAT activity (Figure 5B). Drought stress had no effect on APX activity, which remained comparable to that of the control plant. Treating with 100, 200, and $300 \mu \mathrm{M}$ melatonin showed higher APX activity than the untreated plant, while $100 \mu \mathrm{M}$ yield the most increased APX activity (Figure 5C). Similarly, foliar application with 100, 200, and $300 \mu \mathrm{M}$ melatonin also increased GPX activity compared to the untreated plant, with $100 \mu \mathrm{M}$ being the most effective concentration to increase GPX activity (Figure 5D).
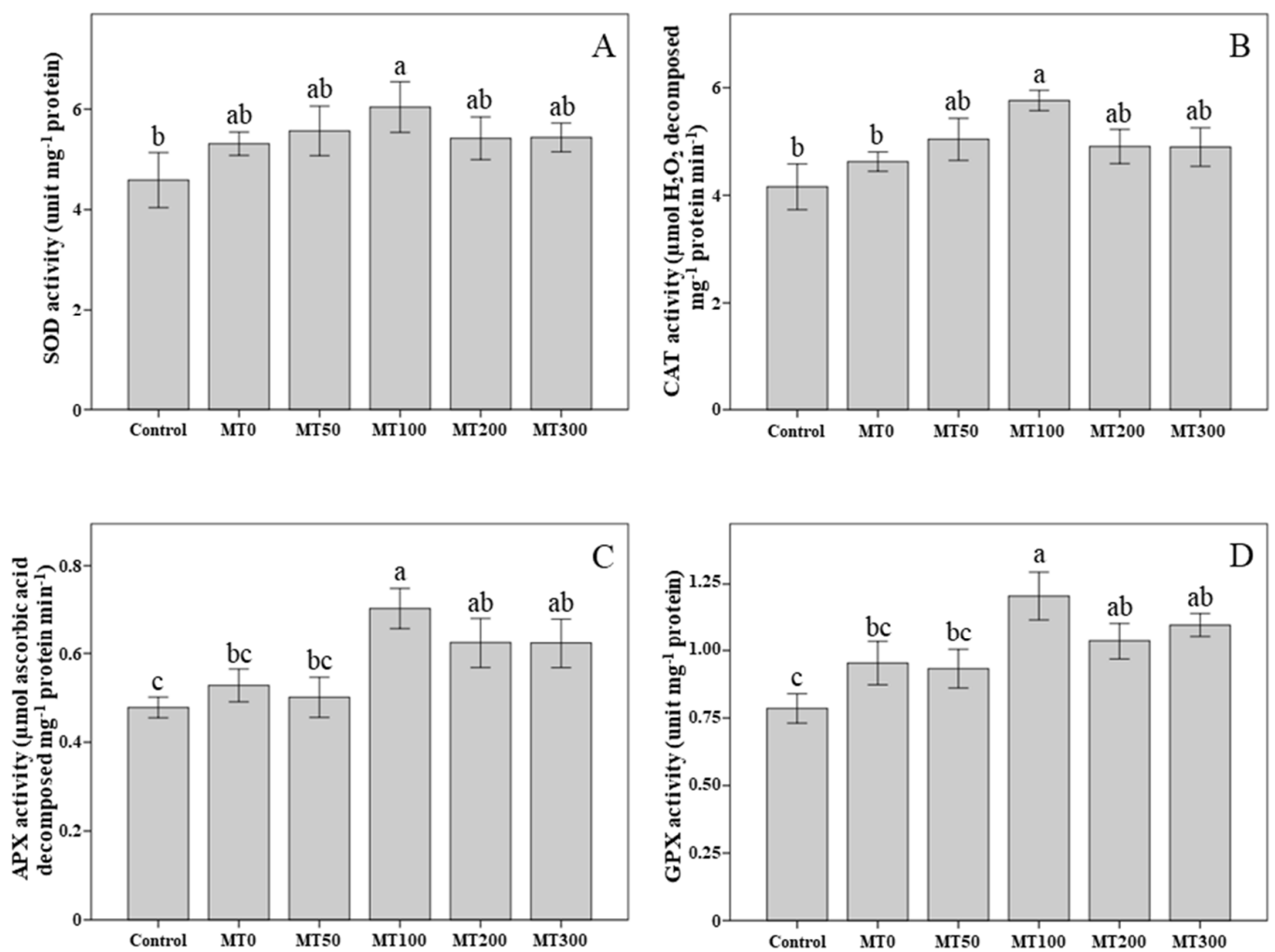

Figure 5. Effects of exogenous melatonin on antioxidant enzyme activities in rice seedling leaves under drought stress represented by the activities of antioxidant enzymes namely superoxide dismutase (SOD) (A), catalase (CAT) (B), ascorbate peroxidase (APX) (C), and guaiacol peroxidase (GPX) (D) Data represent mean \pm SE of 5 replicate samples. Different letters indicate significant differences according to Duncan's multiple range tests $(P<0.05)$ 


\section{Discussion}

Drought stress inhibits rice seedling growth due to lower turgor pressure, reduction in photosynthesis, and cellular damage caused by ROS. However, our findings indicate that exogenous melatonin can alleviate the inhibition of plant growth caused by drought stress. Foliar application with $100 \mu \mathrm{M}$ melatonin presents higher shoot and root growth in rice seedlings, whereas 200 and $300 \mu \mathrm{M}$ melatonin results in decreased root growth. The effect of melatonin on the improvement of plant growth was also reported in maize (Ahmad et al., 2019) and kiwifruit seedlings (Liang et al., 2019). Melatonin is a plant growth regulator and plays a vital role in regulating plant growth and development (Arnao and Hernández-Ruiz, 2015). One of the most intriguing aspects of research on melatonin in plants is the postulated similarity between its function and that of IAA (indole 3-acetic acid). IAA is an auxin involved in various physiological processes, the most notable of which is its role as a growth promoter (Arnao and Hernández-Ruiz, 2006). It is believed that melatonin and IAA can have a co-regulatory impact on plant growth by working in a combined or similar fashion to promote root morphogenesis (Murch et al., 2001). Depends on the concentration of melatonin, it can either promote or inhibit root growth which affects the water uptake process. Melatonin-induced root growth leads to a more efficient acquisition of soil water and nutrients, therefore enhancing the growth in the aerial part of the plant (Arnao and Hernández-Ruiz, 2017).

Drought stress impairs various physiological processes, including chlorophyll degradation, lower relative water content, and cellular membrane damages, as evidenced by increased electrolyte leakage and MDA content. The results in this study indicated that an appropriate concentration of exogenous melatonin could mitigate the detrimental effects of drought stress and improve many physiological parameters. Drought stress stimulates the production of ROS in plant cells, resulting in chlorophyll degradation (Yordanov et al., 2000). Chlorophyll degradation is also accelerated by the chlorophyllase enzyme, and the transcription level of the gene encoding this enzyme is upregulated in response to drought stress (Wang et al., 2013; Ma et al., 2018). Our findings indicate that exogenous melatonin can improve chlorophyll content in the drought-stressed plant. Additionally, previous research has demonstrated that exogenous melatonin can reduce the droughtinduced chlorophyll degradation and improve photosynthetic rate in tomato, cucumber, and maize (Liu et al., 2015; Wang et al., 2016; Ahmad et al., 2019). Melatonin treatment may help prevent chlorophyll degradation by down-regulating the gene encoding the chlorophyllase enzyme. (Sharma et al., 2020).

Drought-induced ROS overproduction in plant cells leads to oxidative stress and lipid peroxidation, which causes cellular damage, membrane dysfunction, and death. Our results indicate that drought induces $\mathrm{H}_{2} \mathrm{O}_{2}$ accumulation as well as increases electrolyte leakage and MDA content. Exogenous application of melatonin contributes to the reduction of ROS accumulation and membrane damage, as evidenced by the decrease in $\mathrm{H}_{2} \mathrm{O}_{2}$, electrolyte leakage, and MDA content. Additionally, melatonin has been shown to reduce electrolyte leakage and MDA content in Cucumis sativus $\mathrm{L}$. and Moldavian balm under moderate and severe drought stress (Zhang et al., 2013; Naghizadeh et al., 2019). Melatonin also acts as a powerful scavenger of ROS in plants (Arnao and Hernández-Ruiz, 2015). In the present study, melatonin application reduces $\mathrm{H}_{2} \mathrm{O}_{2}$ content in the leaf, which is consistent with several previous studies (Zhang et al., 2013; Ye et al., 2016; Liang et al., 2018). Moreover, plants have evolved scavenging systems against ROS, including antioxidant enzymes, to maintain a balance between ROS production and removal. In this study, our results indicate that the activities of the antioxidant enzymes, including SOD, CAT, APX, and GPX, were higher when treated with melatonin under drought stress. The role of melatonin in regulating oxidative stress and ROS in plants, through redox enzymes including SOD, CAT, Peroxidase (POX), APX, and glutathione reductase (GR) has been demonstrated (Arnao and Hernández-Ruiz, 2019). Similar results were reported in rapeseed seedlings (Li et al., 2018), naked oat seedlings (Gao et al., 2018), maize seedlings (Su et al., 2019), and Chinese hickory plants (Sharma et al., 2020), which showed the capability of melatonin to enhance antioxidant enzyme under drought stress. The increased antioxidant enzyme activity may help reduce ROS accumulation, lower lipid peroxidation, and cellular damage, resulting in higher relative water content and lower membrane damage. 
In addition to the response of the antioxidant system, the ability of plants to withstand drought involves the accumulation of compatible solutes to reduce the osmotic potential and maintain turgor pressure. The over-accumulation of proline is an important indicator of drought stress tolerance in higher plants (Ashraf and Iram, 2005). The results in our study show that proline increased several folds when the plant was under drought stress. Melatonin application, particularly at concentrations of 50 and $100 \mu \mathrm{M}$, increases proline accumulation even more when the plant is under drought stress. The effect of melatonin on improving proline accumulation has also been reported in Zea mays L. (Ahmad et al., 2019) and Coffea arabica L. (Campos et al., 2019). In a previous study, Ding et al. (2018) proposed that melatonin increases the expression of P5CS, a key gene for proline biosynthesis, and stimulated pyrroline-5-carboxylate synthase (P5CS) activity in poplar leaf under methyl viologen stress, indicating that melatonin mediates the biosynthesis of proline during oxidative stress. Our result also shows that melatonin increased sugar accumulation when the plant was under drought stress. Melatonin stimulates the biosynthesis of soluble sugars which is responsible for maintaining the turgor and osmotic pressure of plant cells growing under drought stress (Chen et al., 2020).

\section{Conclusions}

To summarize, this study suggests that foliar application of melatonin could alleviate the adverse effects of drought stress in rice seedling. Melatonin increases plant growth, relative water content as well as chlorophyll content. Foliar spray with exogenous melatonin also increases total soluble sugar content and proline content which may function as compatible solutes. Moreover, melatonin also enhances the antioxidant enzyme activities, thus reducing the drought-induced oxidative damage, as indicated by lower electrolyte leakage, MDA, and $\mathrm{H}_{2} \mathrm{O}_{2}$ content. Melatonin at a concentration of $100 \mu \mathrm{M}$ was found to be the most effective concentration at alleviating the effects of drought stress in rice seedlings.

\section{Authors' Contributions}

Both authors read and approved the final manuscript.

\section{Acknowledgements}

This work was supported by funding from Development and Promotion of Science and Technology talents project (DPST), Thailand and Salt Tolerant Rice Research Group (STRG), Department of Biology, Faculty of Science, Khon Kaen University, Thailand. We also would like to thank Khon Kaen Rice Research Center for supplying rice seeds in this experiment.

\section{Conflict of Interests}

The authors declare that there are no conflicts of interest related to this article. 


\section{References}

Ahmad S, Kamran M, Ding R, Meng X, Wang H, Ahmad I, ... Han Q (2019). Exogenous melatonin confers drought stress by promoting plant growth, photosynthetic capacity and antioxidant defense system of maize seedlings. PeerJ 7793. https://doi.org/10.7717/peerj.7793

Ahmad S, Su W, Kamran M, Ahmad I, Meng X, Wu X, ... Han Q (2020). Foliar application of melatonin delay leaf senescence in maize by improving the antioxidant defense system and enhancing photosynthetic capacity under semi-arid regions. Protoplasma 257(4):1079-1092. https://doi.org/10.1007/s00709-020-01491-3

Apel K, Hirt H (2004). Reactive oxygen species: metabolism, oxidative stress, and signal transduction. Annual Review of Plant Biology 55:373-399. https://doi.org/10.1146/annurev.arplant.55.031903.141701

Arnao MB, Hernández-Ruiz J (2006). The physiological function of melatonin in plants. Plant Signaling and Behavior 1(3):89-95. https://doi.org/10.4161/psb.1.3.2640

Arnao MB, Hernández-Ruiz J (2015). Functions of melatonin in plants: a review. Journal of Pineal Research 59:133-150. https://doi.org/10.1111/jpi.12253

Arnao MB, Hernández-Ruiz J (2017). Growth activity, rooting capacity, and tropism: three auxinic precepts fulfilled by melatonin. Acta Physiologiae Plantarum 39:127. https://doi.org/10.1007/s11738-017-2428-3

Arnao MB, Hernández-Ruiz J (2019). Melatonin: a new plant hormone and/or a plant master regulator? Trends in Plant Science 24:38-48. https://doi.org/10.1016/j.tplants.2018.10.010

Arnao MB, Hernández-Ruiz J (2021). Melatonin as a plant biostimulant in crops and during post-harvest: a new approach is needed. Journal of the Science of Food and Agriculture https://doi.org/10.1002/jsfa.11318

Arnon DI (1949). Copper enzymes in isolated chloroplasts. Polyphenoloxidase in Beta vulgaris. Journal of Plant Physiology 24:1-15. https://doi.org/10.1104/pp.24.1.1

Ashraf M, Iram A (2005). Drought stress induced changes in some organic substances in nodules and other plant parts of two potential legumes differing in salt tolerance. Flora-Morphology, Distribution, Functional Ecology of Plants 200(6):535-546. https://doi.org/10.1016/j.flora.2005.06.005

Bates LS, Waldren RP, Teare ID (1973). Rapid determination of free proline for water-stress studies. Plant and Soil 39:205-207. https://doi.org/10.1007/BF00018060

Campos CN, Ávila RG, de Souza KRD, Azevedo LM, Alves JD (2019). Melatonin reduces oxidative stress and promotes drought tolerance in young Coffea arabica L. plants. Agricultural Water Management 211:37-47. https://doi.org/10.1016/j.agwat.2018.09.025

Chen L, Liu L, Lu B, Ma T, Jiang D, Li J, ... Li C (2020). Exogenous melatonin promotes seed germination and osmotic regulation under salt stress in cotton (Gossypium hirsutum L.) PLoS One 15(1):e0228241. https://doi.org/10.1371/journal.pone.0228241

Cherono S, Ntini C, Wassie M, Mollah MD, Belal MA, Ogutu C, Han Y (2021). Exogenous application of melatonin improves drought tolerance in coffee by regulating photosynthetic efficiency and oxidative damage. Journal of the American Society for Horticultural Science 146(1):24-32. https://doi.org/10.21273/JASHS04964-20

Ding F, Wang G, Zhang S (2018). Exogenous melatonin mitigates methyl viologen-triggered oxidative stress in poplar leaf. Molecules 23:2852. https://doi.org/10.3390/molecules23112852

Dionisio-Sese ML, Tobita S (1998). Antioxidant responses of rice seedlings to salinity stress. Plant Science 135:1-9. https://doi.org/10.1016/S0168-9452(98)00025-9

Dubbels R, Reiter RJ, Klenke E, Goebel A, Schnakenberg E, Ehlers C (1995). Melatonin in edible plants identified by radioimmunoassay and by high performance liquid chromatography mass spectrometry. Journal of Pineal Research 18:28-31. https://doi.org/10.1111/j.1600-079x.1995.tb00136.x

Dubois M, Gilles KA, Hamiton JK, Rebers PA, Smith F (1956). Colorimetric method for determination of sugars and related substance. Journal of Analytical Chemistry 28:350-356. https://doi.org/10.1021/ac60111a017

Farooq M, Wahid A, Kobayashi N, Fujita D, Basra SMA (2009). Plant drought stress: effects, mechanisms and management. Agronomy for Sustainable Development 29:185-212. https://doi.org/10.1051/agro:2008021

Gao W, Zhang Y, Feng Z, Bai Q, He J, Wang Y (2018). Effects of melatonin on antioxidant capacity in naked oat seedlings under drought stress. Molecules 23:1580. https://doi.org/10.3390/molecules23071580

Gong H, Zhu X, Chen K, Wang S, Zhang C (2005). Silicon alleviates oxidative damage of wheat plants in pots under drought. Plant Science 169(2):313-321. https://doi.org/10.1016/j.plantsci.2005.02.023 
Hamurcu M, Sekmen AH, Turkan I, Gezgin S, Demiral T, Bell RW (2013). Induced anti-oxidant activity in soybean alleviates oxidative stress under moderate boron toxicity. Plant Growth Regulation 70:217-226. https://doi.org/10.1007/s10725-013-9793-8

Hayat S, Hayat Q, Alyemeni MN, Wani AS, Pichtel J, Ahmad A (2012). Role of proline under changing environments. Plant Signaling and Behavior 7(11):1456-1466. https://doi.org/10.4161/psb.21949

Heath RL, Packer L (1968). Photoperoxidation in isolated chloroplasts. I. Kinetics and stoichiometry of fatty acid peroxidation. Archives of Biochemistry and Biophysics 125:189-198. https://doi.org/10.1016/00039861(68)90654-1

International Rice Research Institute (2002). Rice-Standard-Evaluation-System_2002. Retrieved 2020 May 30 from http://www.knowledgebank.irri.org/images/docs/rice-standard-evaluation-system.pdf

Li J, Zeng L, Cheng Y, Lu G, Fu G, Ma H, ... Li C (2018). Exogenous melatonin alleviates damage from drought stress in Brassica napus L. (rapeseed) seedlings. Acta Physiologiae Plantarum 40:43. https://doi.org/10.1007/s11738017-2601-8

Li Y, Zhao H, Duan B, Korpelainen H, Li C (2011). Effect of drought and ABA on growth, photosynthesis and antioxidant system of Cotinus coggygria seedlings under two different light conditions. Environmental and Experimental Botany 71:107-113. https://doi.org/10.1016/j.envexpbot.2010.11.005

Liang B, Ma C, Zhang Z, Wei Z, Gao T, Zhao Q, ... Li C (2018). Long-term exogenous application of melatonin improves nutrient uptake fluxes in apple plants under moderate drought stress. Environmental and Experimental Botany 155:650-661. https://doi.org/10.1016/j.envexpbot.2018.08.016

Liang D, Ni Z, Xia H, Xie Y, Lv X, Wang J, ... Luo X (2019). Exogenous melatonin promotes biomass accumulation and photosynthesis of kiwifruit seedlings under drought stress. Scientia Horticulturae 246:34-43. https://doi.org/10.1016/j.scienta.2018.10.058

Liu J, Wang W, Wang L, Sun Y (2015). Exogenous melatonin improves seedling health index and drought tolerance in tomato. Plant Growth Regulation 77(3):317-326. https://doi.org/10.1007/s10725-015-0066-6

Ma X, Jing Z, Burgess P, Rossi S, Huang B (2018). Interactive effects of melatonin and cytokinin on alleviating droughtinduced leaf senescence in creeping bentgrass (Agrostis stolonifera L.). Environmental and Experimental Botany 145:1-11. https://doi.org/10.1016/j.envexpbot.2017.10.010

Mittler R, Vanderauwera S, Gollery M, Breusegem FV (2004). Reactive oxygen gene network of plants. Trends in Plant Science 9(10):490-498. https://doi.org/10.1016/j.tplants.2004.08.009

Murch SJ, Campbell SSB, Saxena PK (2001). The role of serotonin and melatonin in plant morphogenesis: Regulation of auxin-induced root organogenesis in in vitro-cultured explants of St. John's wort (Hypericum perforatum L.). In Vitro Cellular and Developmental Biology-Plant 37:786-793. https://doi.org/10.1079/IVP2001235

Naghizadeh M, Kabiri R, Hatami A, Oloumi H, Nasibi F, Tahmasei Z (2019). Exogenous application of melatonin mitigates the adverse effects of drought stress on morpho-physiological traits and secondary metabolites in Moldavian balm (Dracocephalum moldavica). Physiology and Molecular Biology of Plants 25(4):881-894. https://doi.org/10.1007/s12298-019-00674-4

Polthanee A, Promkhumbut A, Bamrungrai J (2014). Drought impact on rice production and farmers' adaptation strategies in Northeast Thailand. International Journal of Environmental and Rural Development 5(1):45-52. https://doi.org/10.32115/ijerd.5.1_45

Sergiev I, Alexieva V, Karanov E (1997). Effect of spermine, atrazine and combination between them on some endogenous protective systems and stress markers in plants. Comptes Rendus de l'Academie Bulgare des Sciences 51:121124.

Sharma A, Wang J, Xu D, Tao S, Chong S, Yan D, ... Zheng B (2020). Melatonin regulates the functional components of photosynthesis, antioxidant system, gene expression, and metabolic pathways to induce drought resistance in grafted Carya cathayensis plants. Science of the Total Environment 713:136675. https://doi.org/10.1016/j.scitotenv.2020.136675

Shi H, Chen K, Wei Y, He C (2016). Fundamental issues of melatonin-mediated stress signaling in plants. Frontiers in Plant Science 7:1124. https://doi.org/10.3389/fpls.2016.01124

Siriphollakul P, Nakano K, Kanlayanarat S, Ohashi S, Sakai R, Rittiron R, Maniwara P (2017). Eating quality evaluation of Khao Dawk Mali 105 rice using near-infrared spectroscopy. Journal of Food Science and Technology 79:7077. https://doi.org/10.1016/j.lwt.2017.01.014 
Su X, Fan X, Shao R, Guo J, Wang Y, Yang J, ... Guo L (2019). Physiological and iTRAQ-based proteomic analyses reveal that melatonin alleviates oxidative damage in maize leaves exposed to drought stress. Plant Physiology and Biochemistry 142:263-274. https://doi.org/10.1016/j.plaphy.2019.07.012

Sunohara Y, Matsumoto H (2004). Oxidative injury induced by the herbicide quinclorac on Echinochloa oryzicola Vasing. and the involvement of antioxidative ability in its highly selective action in grass species. Plant Science 167:597-606. https://doi.org/10.1016/j.plantsci.2004.05.005

Turner NC (1981). Techniques and experimental approaches for the measurement of plant water status. Plant and Soil 58:339-366. https://doi.org/10.1007/BF02180062

Verbruggen N, Hermans C (2008). Proline accumulation in plants: a review. Amino Acids 35:753-759. https://doi.org/10.1007/s00726-008-0061-6

Wang LY, Liu JL, Wang WX, Sun Y (2016). Exogenous melatonin improves growth and photosynthetic capacity of cucumber under salinity-induced stress. Photosynthetica 54:19-27. https://doi.org/10.1007/s11099-015-01403

Wang P, Sun X, Li C, Wei Z, Liang D, Ma F (2013). Long-term exogenous application of melatonin delays droughtinduced leaf senescence in apple. Journal of Pineal Research 54:292-302. https://doi.org/10.1111/jpi.12017

Wei W, Li QT, Chu YN, Reiter RJ, Yu XM, Zhu DH, ... Chen SY (2015). Melatonin enhances plant growth and abiotic stress tolerance in soybean plants. Journal of Experimental Botany 66(3):695-707. https://doi.org/10.1093/jxb/eru392

Ye J, Wang S, Deng X, Yin L, Xiong B, Wang X (2016). Melatonin increased maize (Zea mays L.) seedling drought tolerance by alleviating drought-induced photosynthetic inhibition and oxidative damage. Acta Physiologiae Plantarum 38:48. https://doi.org/10.1007/s11738-015-2045-y

Yordanov I, Velikova V, Tsonev T (2000). Plant responses to drought, acclimation, and stress tolerance. Photosynthetica 38(2):171-186. https://doi.org/10.1023/A:1007201411474

Zhang N, Sun Q, Zhang H, Cao Y, Weeda S, Ren S, Guo YD (2015). Roles of melatonin in abiotic stress resistance in plants. Journal of Experimental Botany 66:647-656. https://doi.org/10.1093/jxb/eru336

Zhang N, Zhao B, Zhang HJ, Weeda S, Yang C, Yang ZC, ... Guo YD (2013). Melatonin promotes water-stress tolerance, lateral root formation, and seed germination in cucumber (Cucumis sativus L.). Journal of Pineal Research 54:15-23. https://doi.org/10.1111/j.1600-079X.2012.01015.x

Zhang Z, Pang X, Xuewu D, Ji Z, Jiang Y (2005). Role of peroxidase in anthocyanin degradation in litchi fruit pericarp. Food Chemistry 90:47-52. https://doi.org/10.1016/j.foodchem.2004.03.023

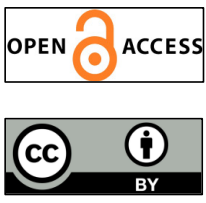

The journal offers free, immediate, and unrestricted access to peer-reviewed research and scholarly work. Users are allowed to read, download, copy, distribute, print, search, or link to the full texts of the articles, or use them for any other lawful purpose, without asking prior permission from the publisher or the author.

License - Articles published in Notulae Botanicae Horti Agrobotanici Cluj-Napoca are Open-Access, distributed under the terms and conditions of the Creative Commons Attribution (CC BY 4.0) License.

(c) Articles by the authors; UASVM, Cluj-Napoca, Romania. The journal allows the author(s) to hold the copyright/to retain publishing rights without restriction. 